\title{
THE MODERNISATION OF THE COURT SYSTEM IN THE GRAND DUCHY OF LITHUANIA: CHANGES TO THE ORGANISATION OF THE LOCAL DISTRICT COURTS AND REGULATION OF JUDGES' DUTIES IN 1764-1793
}

\author{
Ramune Šmigelskyté-Stukienè \\ (Lithuanian Institute of History)
}

\begin{abstract}
In the mid-18th century, with the spread of the ideas of the Enlightenment, fundamental reforms of the state's governance were introduced in the Polish-Lithuanian Commonwealth. Part of the state's modernisation concerned the reform of the court system, considered by 18th-century political theorists to be one of the composite branches of the state administration (alongside the treasury, the police and the army). During the reign of Stanislas Augustus Poniatowski, the work of the courts of first instance underwent reform on several occasions in Poland and Lithuania: with the passing of laws in 1764, 1792 and 1793 on the structure and organisation of the activities of the castle and land courts, the existing court system was changed, as was the procedure for electing judges, also defining the scope of competency of the courts, regulating court activities and the duties of judges, introducing new requirements for the handling of court procedural documents, and the calculation of judges'working hours. During the course of the introduction of these reforms, principles reflecting the administrative ideas of the Enlightenment were gradually entrenched in the court system of the Polish-Lithuanian Commonwealth, which concerned the election of judges and other court officials, the acceptance of collegial decisions, the elimination of the influence of any blood and marital ties, and the principles for remuneration, seeking to introduce stricter requirements for the qualification of judges.

In this article, based on legislation on the organisation of court activities passed at the diets (Sejm) of the Polish-Lithuanian Commonwealth and documents from the dietines (sejmiki) of the Grand Duchy of Lithuania, the author seeks to analyse changes to the activities of the courts and the regulation of judges' duties, and reforms made in the court chanceries between 1764 and 1793.
\end{abstract}

KEYWORDS: Grand Duchy of Lithuania; court reforms; land court; castle court; landowners' court; activities of the court chanceries. 


\section{Introduction}

The system of noble courts that was established in the Grand Duchy of Lithuania in the second half of the 16th century, comprising of land, castle and chamberlain courts, founded during the reforms of 1564-1566, and the right to appeal to the Supreme Tribunal of Lithuania (Tribunal), if needed, which was established in 1581, existed without any major changes for 200 years. But by the beginning of the 18th century, it became evident that this system could no longer serve the needs of the changed society. Among its weakest points were the non-systematised activities of the courts of first instance, or more precisely, the unsuitable organisation of the work of the land, castle and chamberlain courts, and the regulation of judges' duties. There were cases when land courts could not carry out their duties, as the required quorum of judges needed for a court session simply did not assemble.

Fundamental reform of the state's governance was undertaken in the Polish-Lithuanian state in the middle of the 18th century, amid the spread of the ideas of the Enlightenment. Part of the state's modernisation concerned the reform of the court system, considered by 18 th-century political theorists to be one of the composite branches of state administration (alongside the treasury, the police and the army). During the reign of Stanislas Augustus, the work of the courts of first instance underwent reform on three occasions. Having passed laws on the local district (powiat) court structure and the organisation of their activities at the diets of 1764, 1792 and 1793, the existing court system was gradually changed, defining new procedures for the election of judges and the extent of the court's competency, regulating court activities and the duties of judges, and introducing new requirements for the handling of court procedural documents and their record-keeping. During the introduction of these reforms, principles reflecting the administrative ideas of Enlightenment were gradually entrenched in the court system of the Polish-Lithuanian Commonwealth, which concerned the election of judges and other court officials, the acceptance of collegial decisions, and the principles for remuneration, while also seeking to introduce certain requirements for the qualification of judges.

The reform of the noble courts of first instance in the second half of the 18th century in the Grand Duchy of Lithuania (GDL) has not yet been widely analysed. General trends in the improvement 
of the court system have been presented within a wider chronological time frame by Stasys Vansevičius, ${ }^{1}$ while Adam Stankevič, a researcher into the activities of the Supreme Tribunal of Lithuania, who has analysed claims brought before this court against judges of the land and castle courts and chancery staff, summarises the general characteristics of the activities of courts of first instance. ${ }^{2}$ Meanwhile, the topic of the modernisation of the court system has been broached in historiography from just two points of view: a deeper analysis of the codification of laws, ${ }^{3}$ and research into the resolutions of the Department of Justice of the Permanent Council (Rada Nieustajaca) regarding court activities and the implementation of justice in the Polish-Lithuanian Commonwealth. ${ }^{4}$ Only the genesis of the judicial reforms of the 18th century and the functions of the courts under the rule of the Saxonian dynasty and the first years that Stanislas Augustus was in power ${ }^{5}$ have received wider attention, and the issue of restricting the monarch's right to appoint court officials in the dietines of the GDL. ${ }^{6}$

1 S. Vansevičius, 'Lietuvos Didžiosios Kunigaikštystès teismų sistemos tobulinimas XVII-XVIII amžiais', Teisè, t. 45 (2002), pp. 147-153.

2 A. Stankevič, Lietuvos Vyriausiojo Tribunolo veikla XVIII a. II puseje: bajoriškosios teises raiška. PhD dissertation (Vilnius, 2013), pp. 259-289.

${ }^{3}$ W. Szafrański, Kodeks Stanisława Augusta (Poznań, 2007); A. B. Zakrzewski, Wielkie Księstwo Litewskie (XVI-XVIII w.). Prawo - Ustrój - Społeczeństwo (Warszawa, 2013).

${ }^{4}$ M. Głuszak, 'Rezolucje interpretacyjne Rady Nieustającej’, in: Czasopismo Prawno-Historyczne, z. 2 (2013), pp. 73-101; idem., Zbiór rezolucji interpretacyjnych Rady Nieustającej z lat 1786-1788 (Łódź, 2014); idem., 'Funkcjonowanie regestrów sądowych w świetle memoriałów i rezolucji Rady Nieustającej w II połowie XVIII wieku', Studia z Dziejów Państwa i Prawa Polskiego, t. XVI (Kraków, 2013); idem., 'O recepcji prawa w rezolucjach Rady Nieustającej', XVIII amžiaus studijos, t. 3: Lietuvos Didžioji Kunigaikštystè. Iššūkiai. Laimejimai. Netektys, ed. R. ŠmigelskytèStukienè (Vilnius, 2016), pp. 268-281.

${ }^{5}$ J. Michalski, Studia nad reforma sądownictwa i prawa sądowego $w$ XVIII wieku, cz. I (Warszawa, 1958); idem., 'Reforma sądownictwa na sejmie konwokacyjnym 1764 roku', Między wielka polityka a szlacheckim partykularzem. Studia z dziejów nowożytnej Polski i Europy ku czci Profesora Jacka Staszewskiego (Toruń, 1993), pp. 295-313; idem., 'Zagadnienie reformy sądownictwa i prawa sądowego w początkach panowania Stanisława Augusta', Czasopismo Prawno-Historyczne, t. LII, z. 1-2 (2000), pp. 67-107.

${ }^{6}$ A. B. Zakrzewski, 'Ograniczenie przez sejmiki Wielkiego Księstwa Litewskiego monarszego prawa mianowania urzędników sądowych w XVII-XVIII w.', Lietuvos valstybe XII-XVIII a., eds. Z. Kiaupa, A. Mickevičius, J. Sarcevičienè (Vilnius, 1997), pp. 173-186. 
The reorganisation process of local district courts (the creation of landowners' courts) which commenced in 1792 has not yet been systematically researched, and neither has the court reform passed at the Diet of Hrodno of 1793 and its association with the law of the Four-Year Diet on the establishment of landowners' courts received due attention. The activities of the local district courts of the Grand Duchy of Lithuania in the second half of the 18th century have only been touched upon in order to explain the execution of the court's written notarial functions, ${ }^{7}$ when analysing the election of court officials, ${ }^{8}$ or taking a closer look at the career of Antanas Klementas at the Telšiai Land Court. ${ }^{9}$ But the topic of confederate courts from this period has been quite thoroughly researched. ${ }^{10}$ Adam Stankevič described accurately the situation in historiography in his claim that "when we know almost nothing about the activities of the courts of the Grand Duchy of Lithuania, it is basically impossible to talk about the functioning of the system as a whole.' ${ }^{11}$

Taking into account the extent to which this topic has been researched, this paper does not aim to comprehensively analyse the reform of the courts or the practice of how justice was executed in the society of the new age. Of the most important factors concerning the activities of local district courts (the competency of the court, its composition, the organisation of court procedures and practical

${ }^{7}$ R. Šmigelskytè-Stukienè, 'Notarial Functions of the Local District Courts in the Grand Duchy of Lithuania', History of the Lithuanian Notariat, ed. J. Karpavičienè (Vilnius, 2016), pp. 71-93.

${ }^{8}$ W. Filipczak, 'Elekcje ziemskich urzędników sądowych w czasach Rady Nieustającej', Wokót wolnych elekcji w państwie polsko-litewskim XVI-XVIII wieku. O znaczeniu idei wyboru - między prawami a obowiązami (Katowice, 2016), pp. 582-597.

${ }^{9}$ A. Stankevič, 'Antano Klemento karjera Telšių žemės teisme', Teisé. Mokslo darbai, t. 98 (2016), pp. 55-66.

10 J. Sobczak, 'Sąd konfederacji targowickiej województw wielkopolskich 1792-1793 r.', Studia i Materiały do Dziejów Wielkopolski i Pomorza, t. XIII, z. 1 (1979), pp. 163-175; A. Abramski, 'Sądownictwo konfederackie w Polsce w latach 1764-1795', Czasopismo Prawno-Historyczne, t. XXXVI, z. 2 (1984), pp. 145-170; A. Abramski, Sąownictwo podczas konfederacji w Polsce (1672-1793) (Katowice, 1986); В.В. Аніпяркоў, 'Арганізацыя і дзейнасць канфедэрацкіх судоў на землях Вялікага Княства Літоўскага ў 1792-1793 гг.', Гісторыкаархеалагічны зборнік, Вып. 30 (2015), pp. 84-93; R. Šmigelskytè-Stukienè, Lietuvos Didžiosios Kunigaikštystès konfederacijos susidarymas ir veikla 1792-1793 metais (Vilnius, 2003).

11 A. Stankevič, Lietuvos Vyriausiojo Tribunolo veikla XVIII a. II pusèje: bajoriškos teises raiška, p. 259. Stankevič highlights the problems existing in the courts of first instance that had an influence on the workload of the Supreme Tribunal. 
aspects of the court's work), only one aspect of this topic has been chosen for analysis, changes to the regulation of the court's work and the reform of the activities of the court chanceries. Most attention is paid to the land and castle courts. Due to the specific nature of the chamberlain courts (they did not operate in sessions, nor did they have permanent premises or offices), they will not be analysed in this article.

The concept of modernisation has been used to define the reforms of the court system carried out between 1764 and 1793. Taking modernisation to be a complicated and long-term process affecting all spheres of life, during which society is said to undergo a transformation from traditional to modern, ${ }^{12}$ I shall seek to determine whether the reforms introduced in the second half of the 18th century exhibited the characteristics of the emergence of a proto-modern court system (the stability of the activities of court institutions and self-government of the court authorities, encompassing the organisation and administration of court functions, as well as the activities of the body of professional judges), or at least created the conditions for the appearance of these characteristics.

The main source for this research are the laws passed at diets of the Polish-Lithuanian Commonwealth that regulated the organisation and administration of the local district courts, and the resolutions of the dietines of 1790 that reflected the nobility's position regarding the court reforms. Material from the local district courts of the Grand Duchy of Lithuania that reveals the practical activities of the reformed courts and the handling of court documentation is not analysed in this article.

\section{The court reform of 1764: changes in the activities of local district land and castle court chanceries}

The court reform implemented in 1764 was the result of an idea that had matured for many decades to change the legal basis which regulated the activities of the court system. Under the Saxons, their faction together with the Familia, who held that 'in

12 Modernisation is defined as the separation between the public and private spheres, the creation of a professional state apparatus (bureaucracy), and processes of democratisation. For more, see: Z. Norkus, Kokia demokratija, koks kapitalizmas? Pokomunistine transformacija Lietuvoje lyginamosios istorinès sociologijos požiūriu (Vilnius, 2008), p. 76. 
order to ensure the successful functioning of the state apparatus, it is necessary to conduct a reform of the state's administration and its courts, ${ }^{13}$ on many occasions presented draft court reforms to the Diet (Parliament) of the Polish-Lithuanian Commonwealth, seeking that they should be approved as laws. Most attention at this time was devoted to the reform of the Tribunal's activities and the preparation of a new law code, making the reform of the activities of the courts of first instance of secondary importance. However, internal disagreements between factions, and the struggle for influence in the state during the reign of the Saxons, interfered with the implementation of the recommended court system reforms. As a result, none of the three versions of court reform draft laws that were presented at the diet of 1746 were passed. ${ }^{14}$ The same fate befell the drafts prepared by the special deputation at the diet of 1748 , which was meant to prepare amendments to the activities of the Tribunal and other courts. ${ }^{15}$

The possibility to pass laws regulating court activities formed during the interregnum. As early as the Convocation Diet of 1764, a law was passed on the structure of the land courts and the election of judges, which foresaw a land court of four judges and a clerk, abolished the position of deputy judge, and confirmed the provision that clerks could only participate in passing verdicts in cases where the judges' votes were equal. On the death of a clerk, judges were given the right to elect another clerk, who, having 'given a regular oath, could only fulfil his duties until another land court clerk was elected at a dietine'. ${ }^{16}$

The reform of the 1764 Coronation Diet affected the composition of the castle court judges: according to the example of the land court, the number of castle court judges was also increased by two. Palatines and court elders were granted the right to appoint a deputy palatine or deputy elder, three judges and a clerk.

As Adam Stankevič correctly noted, changes to the structure of the court tried to solve the frequent problem of a lack of a quorum, as when even a couple of officials failed to appear at work,

${ }^{13}$ Z. Zielińska, Walka Familii o reformę Rzeczypospolitej 1743-1752 (Warszawa, 1983), p. 111.

${ }^{14}$ Ibid., pp. 213-217.

15 J. Michalski, Studia nad reforma sadownictwa i prawa sadowego w XVIII wieku, p. 111.

16 Sądy ziemskie, Volumina Legum (henceforth - VL), t. 7, pp. 88-89. 
according to the new procedures, three judges were enough to pass a verdict: a clerk could stand in for a judge. And vice versa, one of the judges could temporarily take the position of a clerk who failed to arrive when required. ${ }^{17}$

Election procedures and competency of judges. Having confirmed the land court structure comprising of four judges and a clerk at the Convocation Diet of 1764 in Warsaw, in local districts where deputy judges had already been elected, the latter could become judges without any additional elections. All the remaining local district officials (including the clerk) had to be elected at a dietine by a majority vote. The procedures for the election of judges also changed: local district nobles were given the right to elect not four candidates, but one representative to each court position. ${ }^{18}$ In this way, the local nobility was no longer electing candidates to the positions of land court judge, deputy judge and clerk, but four judges and one clerk. ${ }^{19}$ Thus, the ruler lost his right that had applied since the 16th century to elect one official from four candidates submitted by a local district. ${ }^{20}$

A noble elected to be an official could only give an oath at the castle or land court, and start serving in his new position after receiving the ruler's privilege confirming the dietine's resolution $($ lauda). The procedure for entering the election of judges into the book of acts was regulated with the introduction of the requirement that the dietine's lauda, with all the signatures of the citizens who had voted, or just of the dietine's president and four assessors, first of all had to be entered into the castle chancery books, and only then sent to the ruler, who, based on these documents, would issue his privilege. ${ }^{21}$

The law of 1764 did not introduce a specific term for judges: court officials, as before, were elected for life; but additional qualification requirements were applied to candidates for these positions. The law highlighted that land and castle court officials,

17 A. Stankevič, Lietuvos Vyriausiojo Tribunolo veikla, p. 260.

${ }^{18}$ Sądy ziemskie, $V L$, t. 7, pp. 88-89.

19 Cf. A. Stankevič, Lietuvos Vyriausiojo Tribunolo veikla, p. 260.

20 J. Michalski, 'Reforma sądownictwa na sejmie konwokacyjnym 1764 roku', p. 311; A. B. Zakrzewski, 'Ograniczenie przez sejmiki Wielkiego Księstwa Litewskiego monarszego prawa mianowania urzędników sądowych w XVIIXVIII w.', pp. 183-184.

${ }^{21} V L$, t. 7, p. 171. 
as well as land and castle chancery heads (regents), had to be of noble origin (bene nati), and, observing the provisions of the Statute of Lithuania and the constitutions of 1562 and 1563, had to succeed to land in the palatinate and local district in which they were applying for a court position. Another regulation was introduced whereby two members of the same family could not be judges in the same court. ${ }^{22}$

The qualification requirements for judges were in effect supplemented at the Coronation Diet of 1764. The diet constitution decided who could be chosen to be a land court judge: 'individuals who have never been convicted, and are of sound age and mind' (personas non notatas, aetate et intelligentia vigentes), and who were 'knowledgeable in national law'. ${ }^{23}$ Considering the principle of occupying a position for life, it was important that candidates to these court positions were respected in society, diligent and adequately educated. An especially important requirement was the understanding of 'national law', which we can take to mean being familiar with the rights outlined in the Statutes of Lithuania and the laws of the Polish-Lithuanian Commonwealth.

\section{The regulation of court activities and handling of court docu-} ments. The laws of 1764 regulated the working hours and duration of court sessions. The land court, as before, had to work in terms (sessions); however, one court term had to last for six weeks, and not until all the cases were resolved, as before. Three terms (sessions) were planned for the land court, after the Catholic feast days of the Epiphany, Trinity Sunday and the Feast of St Michael. As for the castle court, instead of the first two weeks of each month, four terms were planned: each had to last four weeks, and start in the first days of March, May, August and December. ${ }^{24}$

Changes to the regulation of court activities took place as early as the diet of 1766, when, taking into account the scope of the cases being deliberated in court, terms were shortened at the Trakai, Braslaw, Rechytsa and Mazyr land courts. These courts were allowed

\footnotetext{
${ }^{22}$ Ibid., p. 89; R. Šmigelskytè-Stukienè, 'Notarial Functions of the Local District Courts in the Grand Duchy of Lithuania', pp. 79-80.

${ }^{23}$ O kondemnatach na WW. Woiewodow lub UU. Starostow Sądowych wypadłych, $V L$, t. 7, p. 178.

${ }^{24}$ Ibid., p. 177; A. Stankevič, Lietuvos Vyriausiojo Tribunolo veikla, p. 260.
} 
to sit for only two terms, which had to begin after the feast of St Michael and the Epiphany. ${ }^{25}$

Whereas a court worked in terms, according to the law of 1764 , the chanceries (the books of acts) of both the castle and the land courts had to sit all year round. The law foresaw that 'land and castle books had to be open, and all books of acts, as well as the issue of extracts from these books, had to be freely accessible to all. ${ }^{26}$

The diet of 1764 also drew attention to how the archives of courts of first instance were kept. Land and castle court officials were authorised to register and bind existing books of acts, indicating precisely to whom they belonged and for whom they were intended, and to keep them safe in specially designated brick archives. ${ }^{27}$ The land court had to have one stamp for certifying documents, with the coat of arms of Lithuania and the title of the palatinate or local district, which officials had to use on verdicts and issued extracts. The stamp had to be kept in the court chancery, while the income received for the issue of certified documents had to be shared equally among the judges. ${ }^{28}$

Two mandatory case registers were introduced in the land and castle courts, following the example of how documents were handled at the Supreme Tribunal: the civil case register (Regestr spraw cywilnych) and the criminal case register (Regestr spraw uczynkowych incarceratorum). ${ }^{29}$ The deliberation of cases in court had to take place according to the order recorded in the register. ${ }^{30}$

Amendments to the working procedures of the land and castle court and the regulation of chancery activities were passed at the diets of 1776 and 1784 . The regulations for keeping court chancery books were supplemented at the diet of 1776 with a resolution on handling procedures for summary-procedural registers (Regestr

25 A. Stankevič, Lietuvos Vyriausiojo Tribunolo veikla, p. 260.

${ }^{26} \mathrm{O}$ księgach i aktach, $V L$, t. 7, p. 179.

${ }^{27}$ Ibid.

${ }^{28} \mathrm{O}$ dochodach urzędom ziemskim i grodzkim, ibid., p. 178.

${ }^{29}$ Regestra w ziemstwach i grodach, ibid., p. 177. In historiography, the incarceratorum register is also known as the 'imprisoned persons' cases register', see: A. Stankevič, Lietuvos Vyriausiojo Tribunolo veikla, p. 16.

${ }^{30}$ Irena Valikonyte highlights the importance of pre-trial documents in court practice in the GDL, noting that even though the public function of these registers was short-lived, they contributed notably to the optimisation of court activities, see: I. Valikonytè, 'Priešteisminių dokumentų funkcijos ir likimas Lietuvos Didžiojoje Kunigaikštysteje XVI a. viduryje: šaukimų registravimo žurnalai’, Istorijos šaltiniu tyrimai, sud. A. Dubonis, t. 4 (Vilnius, 2012), p. 103. 
summarii processus ${ }^{31}$ ), ordinary criminal case registers (Regestr ordynaryjny incarceratorum), and ordinary civil case registers (Regestr ordynaryjny spraw cywilnych), as well as the order in which these cases had to be deliberated. ${ }^{32}$ The land and castle courts were obliged first of all to resolve all cases entered in the summarii processus register, followed by one case at a time from each of the criminal and civil case registers. ${ }^{33}$ The law of 1784 outlined in even greater detail the regulations for the activities of the courts of first instance, obliging the noble courts of the Grand Duchy of Lithuania to abide by the court terms set out in the law, ${ }^{34}$ and to convene on work days (Monday to Saturday) from 8 am to $1 \mathrm{pm}$. The working hours of the court could be shortened by one hour when deemed necessary. ${ }^{35}$

The diet of 1784 also changed the working procedures of the Trakai palatinate's courts: one 12-week term for the land and castle court was introduced. The land court had to sit from 2 November, while the castle court would begin its term on 1 February. The terms of the Valkavysk and Braslaw courts were among the longest, while from the beginning of 1787 , the one-term model for court activity was introduced in many of the courts in the Grand Duchy of Lithuania: the Vilnius, Ashmyany, Vilkmergè (present-day Ukmergè), Kaunas, Raseiniai, Šiauliai, Navahrudak, Brest and Minsk land courts had to sit from 1 October until 31 January the following year. Due to the lower volume of work at the Polotsk and Orsha land courts, their terms were set to end one month earlier, on 31 December. Several court terms remained only at the Mazyr and Rechytsa land court, and the Navahrudak and Mazyr castle courts. ${ }^{36}$

The law of 1787 also regulated the terms of many of the castle courts: the Vilnius, Polotsk and Orsha castle courts had to start their 16-week session on 6 January, while the Brest, Minsk, Ashmyany,

${ }^{31}$ Konstantinas Avižonis has called this the 'monetary register', i.e., it contains lists of cases concerning debts, mortgages, occupied lands and runaway peasants, and other money-related cases. See: „Lietuvos istorijos terminu žodynas“, K. Avižonis, Rinktiniai raštai, t. 2 (Roma, 1978), p. 368.

${ }^{32} V L$, t. 8, pp. 572-573.

${ }^{33}$ A. Stankevič, Lietuvos Vyriausiojo Tribunolo veikla, p. 193 (footnote 1169).

${ }^{34}$ Kadencyów sądowych ubeśpieczenie, $V L$., p. 20.

35 Sesyje sądowe, ibid., p. 21.

${ }^{36}$ Odmiana kadencyi sądów ziemskich i grodzkich dla niektórych wojewódstw i powiatów W.Ks.L., ibid., p. 38; A. Stankevič, Lietuvos Vyriausiojo Tribunolo veikla, pp. 260-261. 
Vilkmerge, Kaunas and Samogitia courts had to start on 1 February. Only the Rechytsa castle court had to sit for three four-week terms (in February, June and September). The terms of the Polotsk and Orsha castle courts had to be shorter, and finish by the end of March. In 1790, the Navahrudak castle court also reverted to one 16-week-long term. ${ }^{37}$

The requirements for handling court documents, which grew steadily from 1764, increased unavoidably the volume of work at court chanceries. An ever-greater number of chancery staff were needed. In addition, the nobility's everyday need to access both court and notarial books of acts encouraged the development of a functioning network of chanceries. Taking into consideration a request by nobles in the Duchy of Samogitia, land and castle court chanceries were established in Telšiai in 1764 in addition to the old centre of this duchy in Raseiniai. However, by the diet of 1775, again taking into account a request from the nobles, these chanceries were transferred from Telšiai to Šiauliai, which was 'more conveniently located' in the Duchy of Samogitia. ${ }^{38}$ Changes also took place in the structure of the court chanceries in the Trakai and Vilnius palatinates. The second court term in the Trakai Palatinate was transferred from Merkine to Alytus, while the second court term in the Ashmyany powiat (local district) was moved from 'useless Myadzyel' to Pastavy. Chanceries facilitating the 'convenient establishment of an archive' had to be founded in the new centres, while brick buildings had to be used for court sessions. The owners of each respective town (the property owners) had to cover the expenses for the establishment of chanceries and the acquisition of buildings. ${ }^{39}$

Procedures for the remuneration of judges. The 1764 law regulated the distribution of income received by land and castle institution officials, and the remuneration of judges. All the income received by a land court had to be shared evenly among all the judges working at that court. The development of the court system, the increase in the volume of judicial documents needed for its everyday

\footnotetext{
${ }^{37}$ Sądy grodzkie województwa nowogródzkiego, VL, t. 9, p. 196; A. Stankevič, Lietuvos Vyriausiojo Tribunolo veikla, p. 261.

38 R. Šmigelskytè-Stukiene, 'Šiaulių reparticija XVIII a. pabaigoje', Šiauliu apskrities istorijos raida. Moksliniu straipsniu rinkinys, ed. J. Sireika (Šiauliai, 2004), pp. 10-24.

${ }^{39} V L$, t. 8, p. 391; R. Šmigelskytè-Stukiene, 'Notarial Functions of the Local District Courts in the Grand Duchy of Lithuania', p. 81.
} 
work, and changes to the state's financial system, determined the introduction of new fees for the documents entered, prepared and issued by chanceries. The constitution of 1764 'On the income of land and castle officials' outlined that for each verdict, ad normam the constitution of 1726, tribunal judges had to receive not a kapa, but a złoty in remuneration from the local district court. ${ }^{40}$

The 1764 reforms to the activities of the courts received the nobility's support, ${ }^{41}$ although new shortcomings in the court systems gradually started to appear. Even though the composition of the court was increased to five people, the problem of a quorum continued to be one of the main factors affecting the institution's work. As Stankevič has noted, land and castle courts judges often failed to carry out their duties, because of their busy involvement in public life, as many were also elected Tribunal judges or deputies to the Diet, or were involved in other activities. ${ }^{42}$ In addition, the sitting of the courts in terms did not guarantee the effective deliberation of cases, and the number of unresolved cases grew steadily. Until the beginning of the 1790s, the work of the land and castle courts in a certain administrative unit of the Grand Duchy of Lithuania had to last from six to seven months of the year in total; however, as the research by Stankevič reveals, there were instances when the court simply did not assemble. ${ }^{43}$

On the other hand, the problem was more than just reaching a quorum of judges. There was great uncertainty among the courts of first instance regarding both the court procedure and the interpretation of the law, as well as the organisation of the courts and their activities. The Department of Justice of the Permanent Council, the central executive government institution, founded in 1775, was not able to resolve all the newly arising legal problems. According to Marcin Gluszak, the Department of Justice, which was responsible for the execution of justice, received most memorials and complaints specifically from the land and castle courts. In the period 1776 to 1786 , as many as $42.1 \%$ of memorials and complaints from the land

${ }^{40} \mathrm{O}$ dochodach urzędom ziemskim i grodzkim, $V L$, t. 7, p. 178; R. ŠmigelskytèStukiene, 'Notarial Functions of the Local District Courts in the Grand Duchy of Lithuania', p. 80.

41 J. Michalski, 'Zagadnienie reformy sądownictwa i prawa sądowego w początkach panowania Stanisława Augusta', pp. 67-107.

${ }^{42}$ A. Stankevič, Lietuvos Vyriausiojo Tribunolo veikla, p. 262.

43 Ibid., pp. 263-273. 
and castle courts examined by the Permanent Council related to the organisation and activity of the courts, $28.8 \%$ related to legal processes, $19.7 \%$ were linked to private law, $2.6 \%$ concerned criminal law problems, and the remainder applied to other issues, regarding tax, the activities of towns and dietines, and ennoblement. ${ }^{44}$ In $1786-1788$, as many as $69 \%$ of all resolutions on laws and courts passed by the Permanent Council related to procedural law and the organisation of the courts and their structure, $21 \%$ affected private law matters, and $1 \%$ concerned criminal law. ${ }^{45}$

The issue of the codification of laws was widely discussed in the public sphere in the Polish-Lithuanian Commonwealth in the $1770 \mathrm{~s}$ to $1780 \mathrm{~s},{ }^{46}$ along with plans for the reform of the nobility's courts. ${ }^{47}$ On the eve of the Four-Year Diet (1788-1792), the idea was put forward to establish an independent administrative court as a court of second instance, which would resolve administrative cases. Lithuanian representatives also had their say in the discussions on court and administrative reforms; one speaker of note was the Bishop of Livonia, Józef Kazimierz Kossakowski, who raised the idea of granting legal and police functions to economic commissions established in each land and local district, and supported the idea of founding a separate administrative court. ${ }^{48}$ Besides the pursuance of the codification of laws (these received special attention during the debriefing dietines of 1788), matters regarding the courts of first instance did not disappear. According to Szafrański, the nobility did not prioritise the preparation of a new legal code, but placed more importance on organising the implementation of justice in the palatinates and local districts. ${ }^{49}$ The law on the reform of courts of first instance was prepared and passed in the autumn of 1788, with the commencement of the Four-Year Diet in Warsaw.

${ }^{44}$ M. Głuszak, 'Rezolucje interpretacyjne Rady Nieustającej', pp. 74-75.

${ }^{45}$ M. Głuszak, Zbiór rezolucji, pp. 313-314.

46 W. Szafrański, Kodeks Stanisława Augusta, pp. 36-57.

${ }^{47}$ J. Malec, Polska myśl administracyjna XVIII wieku (Kraków, 2008), pp. 116-117.

${ }^{48}$ In Kossakowski's opinion, holding both administrative and court positions had to follow a gradual progression, advancing from lower positions to higherranking posts, and without a doubt, they had to offer remuneration. For more on this topic, see: ibid., p. 108.

49 W. Szafrański, Kodeks Stanisława Augusta, p. 43. 


\section{Court reform by the Four-Year Diet: the establishment of a landowners' court}

Whereas the court reform of 1764 was just a partial attempt to modernise the administration of justice in the Polish-Lithuanian Commonwealth, the court system that had functioned since the 16th century was changed fundamentally by the law passed at the Four-Year Diet, which abolished castle, land and chamberlain courts, replacing them with new institutions for the execution of justice, and introducing new principles for the formation of a body of judges and their terms of tenure.

The court reform project prepared by those around Stanislas Augustus was presented to the nobility through the efforts of the king's supporters on the eve of the electoral dietines of 1790. The drafters of the law expected the support of the nobility on these matters: 1) changing the court system, combining the courts of first instance into one institution; 2) introducing terms of tenure for judges; and 3) guaranteeing more effective work by the courts, strengthening judges' personal liability in courts by introducing mandatory books where court verdicts would be entered (sentencjonarz).

The dietines that assembled in November 1790 showed that the nobility in the local districts did seek court reform, but had a different opinion on both the court system and the terms of court judges, and their election procedures. Of the 21 dietines in the Grand Duchy of Lithuania and Livonia, 15 expressed their opinions on courts of first instance (the number of courts, the introduction of judges' terms of tenure, court procedures and court documentation). ${ }^{50}$ The nobility of the Vilnius dietine ordered its deputies to the Diet to demand that court officials 'be elected to castle positions in local districts and palatinates from the dietine', and that 'all officials be elected and appointed not for life, but for five-year terms'. ${ }^{51}$ The dietines were in favour of both land and castle courts sitting for the whole year 'if there were any unresolved cases', ${ }^{52}$ but had no comments on the unification of the courts.

${ }^{50}$ See the publication of dietine instructions: Lietuvos Didžiosios Kunigaikštystès seimeliu instrukcijos (1788-1790), eds. R. Jurgaitis, A. Stankevič, A. Verbickienè (series Fontes historiae parlamentorum Lituanicorum, vol. I) (Vilnius, 2015).

$511790 \mathrm{~m}$. lapkričio $17 \mathrm{~d}$. Vilniaus vaivadijos seimelio instrukcija, Lietuvos Didžiosios Kunigaikštystès seimeliu instrukcijos, p. 51.

52 Ibid. 
When the nobility in the local district of Vilkmerge had heard the king's instructions read by his 'agent', the Vilkmerge land judge Aloyz Kościałkowski, on 16 November 1790, it approved of the recommended modernisation of the courts, stressing that the dietine's deputies to the Diet had to ensure that 'all court officials, both of the castle and land courts, be elected by the nobility itself, and not for life, but for a certain period'. ${ }^{53}$ However, in the opinion of the Vilkmerge nobles, set terms for judges should only be introduced in the future, and should not apply to judges elected prior to the reform. The dietine instructions said that 'all officials currently holding these positions should keep them at their prerogative and authority, according to the old law. ${ }^{54}$ The nobles of Vilkmerge approved of another point in the court reform draft, mandatory introduction of the sentencjonarz, without exception. ${ }^{55}$

The dietines of Kaunas, Upyte, Orsha and Valkavysk also supported the introduction of the sentencjonarz. In addition, the Valkavysk nobility approved of the provision that the fee for court verdicts be set down in law. The nobility in this local district also believed that 'court procedure should be improved', and demanded that a permanently sitting court institution should be introduced, so that the 'Valkavysk castle and land courts would sit constantly and not just for 16 weeks', as there were 'many unresolved cases'. ${ }^{56}$

The Brest dietine also paid close attention to changes in the procedure for the election of judges, and the more detailed regulation of the activities of court chanceries. In its instructions, deputies were ordered to demand that court procedures be shortened, and that both land and castle judges be elected 'not for life, but just for three years'. ${ }^{57}$ However, one exception was suggested: to keep the elder Kazimierz Nestor Sapieha in his post for life. Just like the nobility in other local districts, the Brest dietine also approved of the intro-

53 A. Šapoka, Raštai. T. 2: Lietuva reformu Seimo metu iki 1791 m. gegužès 3 d. Konstitucijos, eds. R. Jurgaitis, R. Šmigelskytė-Stukienè (Vilnius, 2008), p. 327.

${ }^{54}$ The 18 November 1790 instruction of the Vilnius palatinate dietine, Lietuvos Didžiosios Kunigaikštystès seimelių instrukcijos, p. 85.

55 Ibid.

56 The 18 November 1790 instruction of the Valkavysk dietine, ibid., p. 266. Cf. A. Šapoka, Raštai, p. 352.

${ }^{57}$ Ibid., pp. 375-358. 
duction of the sentencjonarz, adding that this kind of register was necessary, so that 'judges be held accountable for their opinions'. ${ }^{58}$

The nobility of the Navahrudak palatinate, ${ }^{59}$ and the Orsha ${ }^{60}$ and Pinsk ${ }^{61}$ local districts, also backed the election of court officials for a specific term, and not for life.

The nobility of the Trakai and Minsk palatinates were in favour of a fundamental reform of the courts, abolishing the castle courts and establishing one court of first instance. However, while the nobility of the Trakai palatinate sought that the new court consist of ten judges elected for life, ${ }^{62}$ the Minsk nobles demanded the introduction of a two-year term for judges elected by local district dietines. ${ }^{63}$ The nobility agreed that this kind of court would sit permanently, and have its own sentencjonarz, so that judges would assume accountability for their decisions. In addition, they demanded an end to nepotism, confirming the ban on the election of several individuals from one family as judges. There were also demands to enforce the principle of a division of duties: judges elected for a two-year term could not stand for election to either the Diet or the Tribunal. ${ }^{64}$

The nobility from the Duchy of Samogitia spoke in favour of three territorial-legal units, or repartitions, in Samogitia, also demanding that sentencjonarz should start being kept in all courts, where judges would set out their opinions. ${ }^{65}$ Incidentally, the nobles of Samogitia demanded this of their deputies at the debriefing dietines of 1788. ${ }^{66}$ The dietines of Slonim and Rechytsa, meanwhile, who made no demands of their deputies regarding the court reform, did oblige their representatives to the Diet to see that suitable premises be granted for the activities of its castle and court institutions and

58 A. Šapoka, Raštai, pp. 357-358.

59 The 16 November 1790 instruction of the Navahrudak palatinate dietine, Lietuvos Didžiosios Kunigaikštystès seimeliu instrukcijos, p. 229; A. Šapoka, Raštai, p. 350.

${ }^{60}$ The 18 November 1790 instruction of the Orsha dietine, Lietuvos Didžiosios Kunigaikštystès seimeliu instrukcijos, p. 283.

${ }^{61}$ The 18 November 1790 instruction of the Pinsk dietine, ibid., p. 318.

62 The 16 November 1790 instruction of the Trakai palatinate dietine, ibid., p. 100.

6321 November 1790 instruction of the Minsk palatinate dietine, ibid., pp. 332-333.

${ }^{64}$ A. Šapoka, Raštai, pp. 365-366.

${ }^{65}$ Ibid., p. 339.

${ }^{66} 20$ August 1788 instruction of the dietine of the Duchy of Samogitia, Lietuvos Didžiosios Kunigaikštystès seimeliu instrukcijos, p. 166. 
archive, such as the former Slonim Jesuit house and all its buildings, ${ }^{67}$ while the Rechytsa nobility 'requested' the former Jesuit house in Babruysk, where it intended to establish the land and castle court, commissions, the local district counter, and an archive for all these institutions on its lower floors. ${ }^{68}$ The Pinsk nobility tried to assume control of the former Jesuit pharmacy building for the needs of its local district court in the winter of 1790 , noting that there were no other suitable premises for the court's everyday workings in the town of Pinsk, which had turned to rubble. ${ }^{69}$

Preparation work in the Diet for the court reform took more than a year. The Diet only passed the law on the founding of a landowners' court (sad ziemianski), instead of the abolished land and castle courts, on 10 January 1792. New landowners' courts, consisting of judges elected for four-year terms, were formed. These courts would not work only during sessions, like the earlier land and castle courts, but would sit all year round. The reformed landowners' court chanceries that were established in both the old and the new administrative units in the state took over the functions of the combined castle and land courts ${ }^{70}$. In this way, 34 courts of first instance were established in the Grand Duchy of Lithuania.

The new court of first instance consisted of ten judges. However, compared to the reform of 1764 , the organisational changes were not very important. As Adam Stankevič correctly noted, the reform model from 1764 basically remained in place: two sets of judges (each with five individuals) were to take turns in assembling, while a quorum would still be the same three judges. ${ }^{71}$ On the other hand, the reform of 1792 did introduce essential innovations: the principle of a distinction of duties was confirmed. The law foresaw that

6710 February 1790 instruction of the Slonim dietine, ibid., pp. 241, 246.

6819 November 1790 instruction of the Rechytsa dietine, ibid., p. 363.

698 February 1790 instruction of the Pinsk dietine, ibid., p. 311.

${ }^{70}$ In order to centralise and modernise the state's governance and improve local self-government activities, from 2 November 1791 a new law on administrative divisions came into effect in the Grand Duchy of Lithuania. Like Greater Poland and Lesser Poland, the Grand Duchy of Lithuania was divided into ten palatinates and 34 local districts (powiats). Eight new administrative units (local districts) were formed in Lithuania. Eight cities (towns) in the Grand Duchy of Lithuania became administrative centres, local district 'capitals': Merkinè, Pastawy, Prienai, Telšiai, Kobryn, Stolin, Slutsk and Eišiškès. Local government institutions started being established in these centres.

${ }^{71}$ A. Stankevič, Lietuvos Vyriausiojo Tribunolo veikla, p. 263. 
of the ten new land court officials, only one could simultaneously serve as a Tribunal judge, and only one could hold the post of deputy to a Diet. $^{72}$

The most important change in the court system was that with the introduction of the landowners' courts, the principle of stability of the activities of court institutions, which was characteristic of a modern society, was confirmed, as were the detailed regulation of duties, and a definition of the court administration model.

Procedures for the election and competency of judges. Based on the law of 1792, landowners' court judges had to be elected at deputy dietines for a four-year term. However, the law allowed the same judges whose terms had expired to stand for re-election. An additional requirement was that all elected local district court officials had to comply with the conditions set out in Articles VI and VII of the 'Law on Dietines'. That is, they had to be of noble origin, have no criminal record, they had to own land in the local district they were standing in to be elected, and also to have experience of some kind of public activity. Experience of public activity (alongside duties in institutions of local district government) could be the acknowledged position of regent in the court chancery. ${ }^{73}$ The landowners' court law also introduced new restrictions for candidates. A judge could not: 1) have the same surname as another candidate, or be related by marriage (son-in-law or father-in-law); 2) have been tried and convicted at court himself, or still have a court case pending; 3 ) have been dismissed from his duties as a judge in accordance with a higher court verdict. In addition, no more than one individual could be elected as deputy to the diet from one court structure, and no more than one could be elected as a Tribunal deputy. ${ }^{74}$

Note that the law of 1792 overrode the constitution of the 1764 Coronation Diet on the necessity of the ruler's privilege introducing the provision that a court official elected at a dietine had to receive its lauda, which would serve as the basis for his election, rather than the ruler's privilege. An official had to take his oath immediately at the location of the election. Once elected, the official could stand down from his duties up to six weeks before the start of the dietine,

\footnotetext{
${ }^{72}$ Sąd ziemiański, VL, t. 9, p. 371; A. Stankevič, Lietuvos Vyriausiojo Tribunolo veikla, p. 263.

${ }^{73}$ Deklaracya o sądach ziemiańskich w Wielkim Xięstwie Litewskim, ibid., p. 379.

${ }^{74}$ Sąd ziemiański, ibid., p. 371.
} 
and after entering the declaration of resignation in the landowners' book of acts, he still had to continue serving until another judge was elected to the post. If during a four-year term any of the judges were to pass away, become a senator, minister or commissar, or enter military service, another judge had to be elected to the post at the next dietine. ${ }^{75}$

\section{Election procedures of other court officials and the regulation} of their duties. Unlike judges, the landowners' court clerk had to be unanimously elected for a seven-year term by all participating court officials, or by a majority in a secret ballot. The law gave detailed regulations concerning the clerk's duties: 1) to participate in court with advisory rights; 2) to register the participation of judges in court sessions, recording both the day and the time when they convened; 3) to keep court protocols and registers in order, write the verdicts in Polish and read them aloud on behalf of the court, and issue them in accordance with the parties' request; 4) to accept entries presented by the parties after the confirmation of their court summons, and to enter them in the registers; 5) to enter court-approved legal transactions in the books of acts.

The clerk had to be at court every day. Exceptions could only be made under very important circumstances, or if the clerk fell ill. In such cases, the court had to appoint a temporary clerk, who had to serve in that capacity after taking an oath. ${ }^{76}$

Besides the court clerk, another position was introduced in the landowners' court, the landowners' acts clerk. Unlike the court clerk, who was elected by the judges, the landowners' acts clerk had to be elected at deputy dietines; however, his activities were controlled by the landowners' court. This clerk could choose sworn-in regents and other chancery personnel at his own discretion to help carry out his duties, but he would be held personally liable for their actions before the local district landowners' court.

The law foresaw the following regulations for the duties of the landowners' court acts clerk: 1) to maintain carefully the archive and chancery; 2) to accept documents for entry into books of acts, and handle documents of confirmation or receipt and transaction contracts written in Polish; 3 ) to issue extracts; 4) to mange record-keeping in the books of acts; and 5) to supervise the work of regents and other

\footnotetext{
75 Ibid.

${ }^{76}$ Ibid., p. 373.
} 
chancery personnel, and ensure the proper protection and handling of the landowners' archive. As soon as the clerk commenced working in this post, he had to take over both the land and the castle acts archive. Each official from the former institution handing over its respective archive had to provide a register of all the cases, while the new clerk had to check and sign it at the time of acceptance. After that, the general register of the accepted books of acts had to be presented to the court for checking, a task for which a separate commission had to be formed. ${ }^{77}$

The acts clerk was appointed to the position for life. A new acts clerk could only be elected after his predecessor had died, or resigned after being called up for military service, or dismissed for violation of his professional duties. A clerk could not leave his duties until all the requirements for the transfer of tasks had been met: he had to present a transfer act for the entire local district archive, and confirmation from the landowners' court regarding his resignation. ${ }^{78}$

The judges of the landowners' court had to reach a majority vote for the public prosecution branch of the landowners' court, an instigator and two court officers (woźny) responsible for serving summons (ministerialis generalis). The instigator had to carry out the court's orders relating to the safety of the court and criminal cases, while the functions of the court officers were to basically carry out all the court's orders. Whereas the law did not go into detail on the procedure for the election of an instigator, requirements for individuals applying for the post of court officer were rather specific. Individuals who 'had earned respect, had no criminal record and were not accused of any criminal activity, and could read and write' could be chosen to serve as the wożny, having first passed a special exam. ${ }^{79}$

The wording of the oaths to the posts of landowners' court clerk and landowners' acts clerk, confirmed in the Law on the Landowners' Court, reflected the new demands placed on court officials. Besides the promise to receive a salary only as foreseen in the law, and not to accept any other payment either before the deliberation of a case or after, as a way of preventing corruption, the wording of these oaths reflected the principle of personal material liability applied to officials working in state institutions in the Age of Enlightenment.

${ }^{77}$ Ibid., p. 374.

${ }^{78}$ Ibid.

79 Ibid. 
The court acts clerk swore neither to demand nor to accept payment greater than that foreseen by the law, even if it was offered by free will, and to carry out his duties knowing he would be held personally and materially liable. ${ }^{80}$

Regulation of functions of the court and organisation of the chancery. The law introduced three landowners' court terms: 1) from 1 April to 30 June; 2) from 1 October to 31 December; and 3) from 1 January to 31 March. Each term had to begin on the given date, regardless of whether it fell on a feast day, and continue until the date outlined in the law. Judges were given three months' holiday: July, August and September. ${ }^{81}$ If it so happened that all the cases were finished, judges were allowed to leave, providing they abided by the conditions set out in the law.

The ten judges elected at the dietine had to divide into two groups of five judges for each term. A judge from one group could not participate in the work of the other group, i.e., outside his set term.

As was mentioned, a quorum of three judges was confirmed to pass verdicts. Court verdicts had to be passed unanimously, or by majority vote. If the votes were equal, lots would be drawn.

The court had to function every day except for Sundays and feast days, from 8 am to $1 \mathrm{pm}$. Court sessions would not be held where the dietines assembled during their gatherings, and for three days after they had ended. Each judge had to arrive at work punctually every day, and remain until the session ended. A special registration book started being kept to ensure that this point in the law was adhered to. Absence was only allowed due to illness, but in such cases the judge had to swear an oath.

The law of 1792 introduced a mandatory court report at the end of each term, which the court had to send to the king via the stamp minister (chancellor) in the Guardianship of Laws (Rada Nieustajaca). The report had to comprise of data about registers and deliberated cases, the number of unresolved cases, and reports about judges' participation in meetings.

The landowners' court in each palatinate and local district had to have a stamp, with the coat of arms of the palatinate or local district, and the inscription 'Stamp of the ... Palatinate (Local District)' for certifying court documents.

${ }^{80}$ Ibid., p. 375.

${ }^{81}$ Ibid., p. 372. 
A detailed procedure for the work of the landowners' courts' and the organisation of the chancery was defined in the 'Declaration on Landowners' Courts in the Grand Duchy of Lithuania', passed in 1792. All the earlier approved land court fees were left as valid in the landowners' courts, and it was also indicated that in each local district where a landowners' court had been founded, and where there was still no infrastructure needed for proper court activities to proceed, premises had to be found to house the court, the chancery, the archive, a holding cell and a prison. ${ }^{82}$

The new court law came into force in February-March 1792. As research into how the reforms were actually implemented has revealed, ${ }^{83}$ the reformed landowners' courts across the whole Grand Duchy of Lithuania made a successful start to their activities, introducing the documentation foreseen by the law, and log-books recording the working hours of judges. ${ }^{84}$ However, the reform of the courts of first instance brought in at the Four-Year Diet lasted only a few months, until June 1792, when the landowners' courts suspended their activities amid the military intervention by the Russian Empire. In the summer of 1792, the confederates, who were gradually assuming power, took the functions of the court and the local district court chanceries into their own hands. ${ }^{85}$ Regardless of the fact that the new confederate courts tried to adopt the activity model of the landowners' courts, by the beginning of 1793 it had become clear that they were incapable of changing the functions of the traditional courts. Dissatisfaction among the nobility grew concerning the implementation of confederate justice. The noble societies were not pleased with the structure of the confederate court and the bias of its judges. ${ }^{86}$ Given

82 Deklaracya o sądach ziemiańskich w Wielkim Xięstwie Litewskim, VL, t. 9, pp. 376-379.

${ }^{83}$ For more on the implementation of these reforms, see: R. Šmigelskytè-Stukienè, 'Už ar prieš reformas: Ketveriu metu seimo nutarimu igyvendinimas Lietuvos Didžiosios Kunigaikštystès pavietuose 1789-1792 metais', Istorija, t. LXXIV/74, (2009/2), pp. 13-22.

${ }^{84}$ Reports sent by landowners' court clerks to the Guardianship of Laws revealed the judges' diligence in convening for sessions and the number of resolved and unresolved cases. For more on this, see: L. Glemža, 'İstatymų sargyba 1792-1793 m.', Modernios administracijos tapsmas Lietuvoje: valstybès instituciju raida 1764-1794 metais, eds. R. Šmigelskytė-Stukienè, E. Brusokas, L. Glemža et. al. (Vilnius, 2014), p. 363.

85 R. Šmigelskyte-Stukienè, 'Notarial Functions of the Local District Courts in the Grand Duchy of Lithuania', pp. 89-92.

${ }^{86}$ For more on the activities of the confederate courts, see: R. ŚmigelskytèStukienè, Lietuvos Didžiosios Kunigaikštystès konfederacijos susidarymas ir veikla, pp. 162-182. 
the circumstances, the confederate leadership was forced to make fundamental changes to the court system. A circular from the General Confederation of Lithuania was issued on 23 March 1793 on the reinstatement of the land courts. ${ }^{87}$ With this agreement, all land courts known as landowners' courts were recognised as legal, along with all the officials who had been elected in 1792. Land judges and elected court officials from each local district were ordered to arrive at the designated court premises on 25 April 1793, and, having taken the oath provided by the Confederation, they had to start carrying out their duties. In this way, after the Second Partition of the Polish-Lithuanian Commonwealth, the courts that had been reformed at the Four-Year Diet resumed their work in the remainder of the Grand Duchy of Lithuania, the only difference being that the title 'landowners' court' was changed back to land court.

\section{The court law passed at the Hrodno Diet of 1793: continuity of the reform}

On 23 November 1793, the reform passed at the Four-Year Diet was in effect confirmed at the Hrodno Diet, only instead of the landowners' court, the title 'land court' was reinstated. Taking into account the state's territorial losses in the Second Partition, the number of courts of first instance and their location was regulated by the new law on administrative divisions. ${ }^{88}$ In this way, in the Grand Duchy of Lithuania, instead of the 34 landowners' courts, 24 land courts of first instance were established. ${ }^{89}$ In those local districts where land or castle courts had functioned earlier, the old premises had to be used for the activities of the courts of first instance (providing they were in suitable condition), while in the newly established land centres, a special foundation formed by the local nobility at a dietine had to ensure a proper court infrastructure, its funds being used for the construction of court buildings, an archive, a holding cell and a prison. The Police Commission had to oversee the creation of the required infrastructure for court activities.

${ }^{87}$ Ibid., p. 175.

88 Sądy ziemskie Wielkiego Księstwa Litewskiego, VL, t. 10, pp. 301-309.

${ }^{89}$ Rozkład, rozporządzenie i podział województw i ziem, ibid., pp. 316-319. 
Election procedures for judges and other court officials, their competency and regulation of their duties. Unlike the reforms of 1792, the Hrodno Diet introduced a six-judge land court; however, judges had to be elected at the local district's dietine for the same four-year term. Judges were allowed to stand for re-election after the end of their initial term. The requirements for individuals seeking to be elected as judges, concerning both the conditions and procedure for a judge's election, and the regulations for resignation from their duties, or the election of a new judge on the death or promotion of his predecessor, were outlined exactly as in the law of 1792 .

The working hours of the court basically remained unchanged, i.e., nine months of uninterrupted court activity per year were confirmed, starting from 1 October and ending on 30 June, giving judges three months' holiday. ${ }^{90}$ However, the new law did not outline regulations for the distribution of court terms.

As before, a quorum consisted of three judges. The judge whose name was entered first on the list of judges elected at the dietine had to preside over court sessions.

As in the law of 1792 , so too in 1793 , a court's verdict had to have a majority of votes, and a mandatory sentencjonarz was introduced, so that a judge who might have had a different opinion could make a record of it, adding his signature.

The same working hours applied, only some additional religious holidays were introduced: from Christmas Eve until New Year's Day, and Holy Week from the Wednesday before Easter until the Wednesday after Easter, and during a dietine and for three days afterwards. Judges not only had to arrive at work punctually, at 8 am, but the court clerk was also obliged to record honestly in the log-book the time when they arrived. Importantly, the law forbade holding court sessions in premises that were not allocated to the court, 'except in cases as outlined by the Tribunal'. ${ }^{91}$

Taking into account the fact that instead of the Guardianship of Laws, the central executive government functions were again in the hands of the Permanent Council, land court reports had to be sent to the Department of Justice of the Permanent Council. In addition, unlike the landowners' court, which had to report to the Guardianship of Laws every quarter (i.e., at the end of each three-month term),

${ }^{90}$ Sądy ziemskie Wielkiego Księstwa Litewskiego, ibid., p. 302.

${ }^{91}$ Ibid., p. 303. 
the land court had to send reports to the Permanent Council every two months. The requirements for these reports remained the same. ${ }^{92}$

Three registers made up the mandatory court documentation: 1) a civil register, which was to include cases that used to be entered in the ordinary and summary registers of the earlier land and castle courts; 2) a tactical register for claims over violations or infringements made at the court itself; and 3) an incarceratorum register for criminal cases.

Court fees remained the same as before, but an instruction was added that a separate resolution on this matter would have to be passed in the future. ${ }^{93}$

Some minor changes were introduced in setting the duration of the land court clerk's term. This official had to be elected for a four-year term, instead of the seven years designated earlier, by unanimous vote of all participating court officials, but his duties remained the same. The court clerk also had the right to invoke the assistance of sworn-in protocol-keepers and chancery personnel, assuming personal liability for their actions.

The Hrodno Diet left as valid the position of court act clerk introduced in 1792, who was responsible for keeping the archive and chancery in order. The clerk elected at the dietine could remain in this position for life. The law foresaw that in cases where the clerk wished to resign from his position (due to promotion or suspension), he had to transfer the whole court archive to the land court, certifying this with his signature. A new requirement passed at the Hrodno Diet was added to the regulations for the acts clerk of 1792 , whereby the clerk had to take responsibility for the books of acts from the no-longer existing local districts, transferring them to the new local districts, and to ensure their preservation.

Taking into account the fact that the Hrodno Diet left the election of landowners' court judges that took place at the dietines in 1792 as valid, ${ }^{94}$ but introduced a six-judge court, the ten-judge court structure was allowed to remain in the old local district for the first four years. If fewer than six judges assembled, the dietine had to elect the remaining number of judges. A six-judge court had to be elected at the new local districts and lands. Judges who owned

\footnotetext{
92 Ibid., pp. 303-304.

${ }^{93}$ Ibid., p. 305.

${ }^{94}$ Ibid., p. 309.
} 
land in the new local districts and who wished to continue serving in their positions could continue working in the land court without having to be re-elected for the first four-year term, even in cases where there were more than six judges.

The Hrodno Diet law on land courts had to ensure the continuous and effective working of the courts of first instance. The surviving books of acts, court case registers and other documents from the Anykščiai, Merkine, Šiauliai, Raseiniai, Telšiai and other local district land courts ${ }^{95}$ reveal the consistent process of the implementation of the law's norms at the beginning of 1794 in the Grand Duchy of Lithuania. However, the Third Partition in 1795 not only stopped the modernisation process of the court, but also destroyed the Polish-Lithuanian state.

\section{Conclusions}

The reform of 1764, which regulated the organisation and administration of the work of the courts, was an important stage in the activities of the noble courts of first instance in the Grand Duchy of Lithuania. The principles it entrenched for the election of judges outlined a five-judge structure and regulated the working hours. The law also regulated the remuneration of judges and other court officials.

The laws passed in 1764-1787 concerning the activities of specific local district castle and land courts sought to make the work of these courts of first instance more effective, setting out a longer court session and regulating the working hours of judges.

The nobility's interest in the reform of the courts of first instance was revealed at the electoral dietines of 1790 , where $71.4 \%$ of the local districts in the Grand Duchy of Lithuania expressed opinions on matters of court reform. The nobility were in favour of introducing terms of tenure for court officials, demanding that two (Minsk), three (Brest) or five-year (Vilnius) terms for judges be introduced. They sought to end nepotism, by not allowing several individuals from one family to be elected as judges, and by introducing a principle of distinguishing between the duties held by an individual.

95 See: Lietuvos valstybès istorijos archyvas (henceforth - LVIA), f. SA, b. $14222,5833,14984,14801,15166$ and other files. The ever-increasing amount of land court documentation was further supplemented by resolved case registers and court session attendance log-books. The existence of a judges' registration logbook is proven by a report to the Permanent Council about the working hours of the Merkine land court judges, which was prepared based on this kind of register, LVIA, f. SA, b. 5833, 1. 303-306v. 
The system of the courts of first instance that had functioned since the 16th century was changed fundamentally at the Four-Year Diet, which in 1792 established one landowners' court, introduced new principles for the formation of a body of judges, and determined terms for judges. From 1792, the diligence of judges in attending court sessions was monitored more closely, with the introduction of a mandatory registration log-book for recording their participation, as well as the regular sending of reports about judges and court activity to a higher supervisory institution, the Guardianship of Laws.

The implementation of the court reform of 1792 formed new, collegial landowners' courts, which consisted of judges elected for four-year terms at deputy dietines. These courts no longer worked in sessions, like the land and castle courts, but functioned constantly throughout the year, thus ensuring stability in the activities of court institutions, which was a sign of a modern society.

Between 1764 and 1793, steadily stricter qualification requirements were expected of court officials. Whereas according to the law of 1764, a noble could become a judge, providing that he owned land in the administrative unit where he was applying to become a court official, was respected in society, of working age, adequately educated and familiar with the rights in the Statutes of Lithuania and the laws of the Polish-Lithuanian Commonwealth, the law of 1792 introduced a new requirement, namely, experience in the public sphere, and outlined clearly that a candidate could not have a previous conviction, and neither could judges who were related through blood or marriage be elected to serve in the same term.

The law of 1792 also confirmed the ban on holding dual duties. The only exception in this case was to allow one of the ten new land court officials to also serve as a Tribunal judge, and one to hold the position of a deputy to the Diet.

With minor amendments, the law passed at the Hrodno Diet of 1793 confirmed the landowners' court reform of 1792. The number of judges elected for a four-year term was reduced from ten to six, their holiday periods were extended, and the tenure of the land court clerk was shortened to equal the tenure of the judges. Stricter control over judges was introduced, with the requirement to send reports on their participation in court sessions and the number of cases they had deliberated on to a higher court institution responsible for monitoring activity, the Permanent Council, though not every quarter, but every two months. 
The reforms of 1792-1793 showed that the characteristics of a proto-modern court system were formed in the courts of first instance: namely, stability in the activities of court institutions, and a degree of autonomy among the court authorities, which included the organisation and administration of landowners' (land) courts regulated by law.

\section{Author Details}

Associate Professor Ramunè Šmigelskytė-Stukienè is a senior researcher at the Department of History of the Grand Duchy of Lithuania of the Lithuanian Institute of History. Her main scholarly interests are the early modern history of the Grand Duchy of Lithuania, and the development of governmental structures of the Polish-Lithuanian Commonwealth in 1764-1794.

Address: Lithuanian Institute of History, Kražių g. 5, Vilnius LT-01108, Lithuania Email: smigelskyte.stukiene@gmail.com

\section{Bibliography}

ABRAMSKI, A. 'Sądownictwo konfederackie w Polsce w latach 17641795', in: Czasopismo Prawno-Historyczne, t. XXXVI, z. 2 (1984), pp. 145-170.

ABRAMSKI, A. Sadownictwo podczas konfederacji w Polsce (16721793) (Katowice, 1986).

AVIŽONIS, K. Rinktiniai raštai, t. 2 (Roma, 1978).

FILIPCZAK, W. 'Elekcje ziemskich urzędników sądowych w czasach Rady Nieustającej’, in: Wokót wolnych elekcji w państwie polsko-litewski m XVI-XVIII wieku. O znaczeniu idei wyboru - między prawami a obowiazkami (Katowice, 2016), pp. 582-597.

GLEMŽA, L. 'İstatymų sargyba 1792-1793 m.', in: Modernios administracijos tapsmas Lietuvoje: valstybès instituciju raida 1764-1794 metais, eds. R. Šmigelskytė-Stukienè, E. Brusokas, L. Glemža, R. Jurgaitis, V. Rakutis (Vilnius, 2014), pp. 350-364.

GŁUSZAK, M. 'Funkcjonowanie regestrów sądowych w świetle memoriałów i rezolucji Rady Nieustającej w II połowie XVIII wieku', in: Studia z Dziejów Państwa i Prawa Polskiego, t. XVI (2013).

GŁUSZAK, M. 'O recepcji prawa w rezolucjach Rady Nieustającej', in: XVIII amžiaus studijos, t. 3: Lietuvos Didžioji Kunigaikštystè. Iššūkiai. Laimejjimai. Netektys, ed. R. Šmigelskytė-Stukienè (Vilnius, 2016), pp. 268-281.

GŁUSZAK, M. 'Rezolucje interpretacyjne Rady Nieustającej', in: Czasopismo Prawno-Historyczne, z. 2 (2013), pp. 73-101.

GŁUSZAK, M. Zbiór rezolucji interpretacyjnych Rady Nieustajacej $z$ lat 1786-1788 (Łódź, 2014).

Lietuvos Didžiosios Kunigaikštystès seimeliu instrukcijos (1788-1790), eds. R. Jurgaitis, A. Stankevič, A. Verbickienė (series Fontes historiae parlamentorum Lituanicorum, vol. I) (Vilnius, 2015).

MALEC, J. Polska myśl administracyjna XVIII wieku (Kraków, 2008). 
MICHALSKI, J. 'Reforma sądownictwa na sejmie konwokacyjnym 1764 roku', in: Między wielka polityka a szlacheckim partykularzem. Studia z dziejów nowożytnej Polski i Europy ku czci Profesora Jacka Staszewskiego (Toruń, 1993), pp. 295-313.

MICHALSKI, J. 'Zagadnienie reformy sądownictwa i prawa sądowego w początkach panowania Stanisława Augusta', in: Czasopismo PrawnoHistoryczne, t. LII, z. 1-2 (2000), pp. 67-107.

MICHALSKI, J. Studia nad reforma sądownictwa i prawa sądowego $w$ XVIII wieku, cz. I (Warszawa, 1958).

NORKUS, Z. Kokia demokratija, koks kapitalizmas? Pokomunistine transformacija Lietuvoje lyginamosios istorinès sociologijos požiūriu (Vilnius, 2008).

SOBCZAK, J. 'Sąd konfederacji targowickiej województw wielkopolskich 1792-1793 r.', in: Studia i Materiały do Dziejów Wielkopolski i Pomorza, t. XIII, z. 1 (1979), pp. 163-175.

STANKEVIČ, A. 'Antano Klemento karjera Telšių žemès teisme', in: Teise, t. 98 (2016), pp. 55-66.

STANKEVIČ, A. Lietuvos Vyriausiojo Tribunolo veikla XVIII a. II pusëje: bajoriškosios teisès raiška. PhD dissertation (Vilnius, 2013).

SZAFRAŃSKI, W. Kodeks Stanisława Augusta (Poznań, 2007).

ŠAPOKA, A. Raštai. T. 2: Lietuva reformu Seimo metu iki $1791 \mathrm{~m}$. gegužès 3 d. Konstitucijos, eds. R. Jurgaitis, R. Šmigelskytè-Stukienė (Vilnius, 2008).

ŠMIGELSKYTĖ-STUKIENĖ, R. 'Notarial Functions of the Local District Courts in the Grand Duchy of Lithuania', in: History of the Lithuanian Notariat, ed. J. Karpavičienè (Vilnius, 2016), pp. 71-93.

ŠMIGELSKYTĖ-STUKIENĖ, R. 'Šiaulių reparticija XVIII a. pabaigoje', in: Šiauliu apskrities istorijos raida, ed. J. Sireika (Šiauliai, 2004), pp. 10-24.

ŠMIGELSKYTĖ-STUKIENĖ, R. Lietuvos Didžiosios Kunigaikštystès konfederacijos susidarymas ir veikla 1792-1793 metais (Vilnius, 2003).

ŠMIGELSKYTĖ-STUKIENĖ, R. 'Už ar prieš reformas: Ketverių metų seimo nutarimų igyvendinimas Lietuvos Didžiosios Kunigaikštystės pavietuose 1789-1792 metais', in: Istorija, t. LXXIV/74 (2009/2), pp. 13-22.

VALIKONYTĖ, I. 'Priešteisminių dokumentų funkcijos ir likimas Lietuvos Didžiojoje Kunigaikštystejje XVI a. viduryje: šaukimų registravimo žurnalai' in: Istorijos šaltiniu tyrimai, t. 4, ed. A. Dubonis (Vilnius, 2012), pp. 93-108.

VANSEVIČIUS, S. 'Lietuvos Didžiosios Kunigaikštystès teismų sistemos tobulinimas XVII-XVIII amžiais', in: Teise, t. 45 (2002), pp. 147-153.

Volumina Legum, t. 9 (Kraków, 1889).

Volumina Legum, t. 7-8 (Petersburg, 1859-1860).

Volumina Legum, t. 10 (Poznań, 1952).

ZAKRZEWSKI, A.B. 'Ograniczenie przez sejmiki Wielkiego Księstwa Litewskiego monarszego prawa mianowania urzędników sądowych w XVII-XVIII w.', in: Lietuvos valstybe XII-XVIII a., eds. Z. Kiaupa, A. Mickevičius, J. Sarcevičienė (Vilnius, 1997), pp. 173-186. 
ZAKRZEWSKI, A.B. Wielkie Księstwo Litewskie (XVI-XVIII w.). Prawo - Ustrój - Społeczeństwo (Warszawa, 2013).

ZIELIŃSKA, Z. Walka Familii o reforme Rzeczypospolitej 1743-1752 (Warszawa, 1983).

АНІПЯРКОЎ, В.В. 'Арганізацыя і дзейнасць канфедэрацкіх судоў на землях Вялікага Княства Літоўскага ў 1792-1793 гг.', in: Гісторыкаархеалагічны зборнік, Вып. 30 (2015), рр. 84-93.

\section{LIETUVOS DIDŽIOSIOS KUNIGAIKŠTYSTĖS TEISMŲ SISTEMOS MODERNIZACIJA: PAVIETO TEISMŲ VEIKLOS ORGANIZAVIMO IR TEISĖJŲ DARBO REGLAMENTAVIMO POKYČIAI 1764-1793 M.}

Santrauka

\section{RAMUNE் ŠMIGELSKYTE்-STUKIENE்}

Lenkijos ir Lietuvos valstybejje - Abiejų Tautų Respublikoje - XVIII a. viduryje buvo imtasi esminių valstybės valdymo pertvarkų. Valstybès modernizacijos dalimi tapo teismų sistemos, XVIII a. policistų laikytos viena iš sudėtinių valstybinès administracijos šakų (greta iždo, policijos ir karo sričių), reformavimas. Stanislovo Augusto Poniatovskio valdymo laikotarpiu Lenkijoje ir Lietuvoje kelis kartus buvo pertvarkomas pirmosios instancijos teismų darbas: prièmus 1764, 1792 ir $1793 \mathrm{~m}$. ịstatymus dèl Pilies ir Žemès teismų struktūros ir jų veiklos organizavimo, buvo keičiama tiek egzistavusi teismų sistema, tiek teisėjų rinkimo tvarka, apibrěžta teismo kompetencija, reglamentuota teismo veikla ir teisèjų darbas, ịvesti nauji reikalavimai dèl teismo procesinių dokumentų tvarkymo ir teisejjų darbo laiko apskaitos. Šių pertvarkų metu Abiejų Tautų Respublikos teismų sistemoje pamažu buvo ịtvirtinti Apšvietos epochos administracinę mintį atliepiantys teisèjų ir kitų teismo pareigūnų renkamumo, kolegialaus sprendimų prièmimo, giminystès ir svainystės ryšių eliminavimo, apmokèjimo už darbą principai, siekta ịvesti griežtesnius kvalifikacijos reikalavimus teisejams.

Straipsnyje, išanalizavus teismo veiklos ir teisèjų darbo reglamentavimo pokyčius 1764-1794 m. laikotarpiu, prieinama prie išvadų, kad $1764 \mathrm{~m}$. teismų reforma buvo tik dalinis bandymas modernizuoti pirmosios instancijos teismų sistemą. Esminių pokyčiu padarè Ketverių metų seimo įstatymas dèl Žemionių teismo įsteigimo. Igyvendinus $1792 \mathrm{~m}$. teismų reformą buvo suformuoti nauji, kolegialūs Žemionių teismai, kuriuos sudarè teisèjai, renkami ketveriems metams deputatiniuose seimeliuose. Tokie teismai dirbo nebe sesijomis, kaip Žemès ar Pilies teismai, bet veikè nuolat, visus metus, taip užtikrindami moderniai visuomenei būdingą teismo institucijų veiklos pastovumą. $1793 \mathrm{~m}$. Gardino seimo įstatymas su nedideliais pakeitimais įtvirtino $1792 \mathrm{~m}$. Žemionių teismo reformą.

1792-1793 m. reformos parode, kad pirmosios instancijos teismų sistemoje buvo suformuoti protomodernios teismų sistemos bruožai - teismo institucijų veiklos pastovumas ir teisminès valdžios savivalda, apimanti įstatymo reglamentuotą Žemionių (Žemès) teismo darbo organizavimą ir administravimą. 